\title{
External and gastrointestinal parasites of the rufous-collared sparrow Zonotrichia capensis (Passeriformes, Emberizidae) in Chile
}

Parasitas gastrointestinais e externos do tico-tico Zonotrichia capensis (Passeriformes, Emberizidae) do Chile

Sebastián Llanos-Soto ${ }^{1}$; Braulio Muñoz ${ }^{2}$; Lucila Moreno ${ }^{1}$; Carlos Landaeta-Aqueveque ${ }^{2}$; John Mike Kinsella ${ }^{3}$;

Sergey Mironov ${ }^{4}$; Armando Cicchino ${ }^{5}$; Carlos Barrientos ${ }^{6}$; Gonzalo Torres-Fuentes ${ }^{2}$; Daniel González-Acuña ${ }^{2 *}$

\author{
${ }^{1}$ Facultad de Ciencias Naturales y Oceanográficas, Universidad de Concepción, Concepción, Chile \\ ${ }^{2}$ Facultad de Ciencias Veterinarias, Universidad de Concepción, Chillán, Chile \\ ${ }^{3}$ Helm West Lab, Missoula, MT, USA \\ ${ }^{4}$ Zoological Institute, Russian Academy of Sciences, Universitetskaya Embankment 1, Saint Petersburg, Russia \\ ${ }^{5}$ Universidad Nacional de Mar del Plata, Mar del Plata, Argentina \\ ${ }^{6}$ Escuela de Medicina Veterinaria, Universidad Santo Tomás, Concepción, Chile
}

Received March 9, 2017

Accepted June 9, 2017

\begin{abstract}
A total of 277 rufous-collared sparrows, Zonotrichia capensis Müller, 1776 (Emberizidae), were examined for external parasites. The birds were captured using mist nets in seven locations in northern and central Chile. Additionally, seven carcasses from central Chile (the Biobío region) were necropsied to evaluate the presence of endoparasite infection. Ectoparasites were found on 35.8\% (99/277) of the examined birds and they were represented by the following arthropods: feather mites Amerodectes zonotrichiae Mironov and González-Acuńa, 2014 (Analgoidea: Proctophyllodidae), Proctophyllodes polyxenus Atyeo and Braasch, 1966 (Analgoidea: Proctophyllodidae), and Trouessartia capensis Berla, 1959 (Analgoidea: Trouessartiidae); a louse Philopterus sp. (Phthiraptera: Ischnocera); and ticks Amblyomma tigrinum Koch, 1844 (Acari: Ixodidae) and Ixodes auritulus Neumann, 1904 (Acari: Ixodidae). Two of the seven necropsied carcasses were infected with the acanthocephalan Mediorhynchus papillosus Van Cleave, 1916 (Gigantorhynchida: Gigantorhynchidae). To our knowledge, this study reports P. polyxenus, Philopterus sp., A. tigrinum, and M. papillosus for the first time for $Z$. capensis and expands the distributional range for T. capensis to Chile.
\end{abstract}

Keywords: Ectoparasites, endoparasites, lice, mite, tick, Zonotrichia capensis.

\section{Resumo}

Um total de 277 tico-tico Zonotrichia capensis Müller, 1776 (Emberizidae) foram examinados em busca de ectoparasitos. As aves foram capturadas com redes em sete localidades do norte e centro do Chile. Além disso, sete carcaças do centro Chile (Regiáo de Biobío) foram examinadas para avaliar a infecção por endoparasitos. Ectoparasitos foram encontrados em 35,8\% (99/277) das aves examinadas com a identificaçáo dos ácaros Amerodectes zonotrichiae Mironov and González-Acuña, 2014 (Analgoidea: Proctophyllodidae), Proctophyllodes polyxenus Atyeo and Braasch, 1966 (Analgoidea: Proctophyllodidae) e Trouessartia capensis Berla, 1959 (Analgoidea: Trouessartiidae), piolho Philopterus sp. (Phthiraptera: Ischnocera) e carrapatos Amblyomma tigrinum Koch, 1844 (Acari: Ixodidea) e Ixodes auritulus Neumann, 1904 (Acari: Ixodidea). Duas das sete carcaças examinadas foram infectadas com o Acantocephala Mediorhynchus papillosus Van Cleave, 1916 (Gigantorhynchida: Gigantorhynchidae). Para o nosso conhecimento, este é o primeiro estudo para descrever P. polyxenus, Philopterus sp., A. tigrinum e M. papillosus em $Z$. capensis e expande a distribuição de T. capensis ao Chile.

Palavras-chave: Ectoparasitos, endoparasitos, piolho, ácaro, carrapato, Zonotrichia capensis. 


\section{Introduction}

The rufous-collared sparrow, Zonotrichia capensis Müller, 1776 (Emberizidae), inhabits almost all environments of the New World spanning from southern Mexico to Tierra del Fuego (Chile), excluding any areas covered with dense forests (CHESTER, 2008). This bird species can be found in cities and any other areas where forests have been cleared due to human activity; it also occurs at high altitudes, such as in the Altiplano (MILLER \& MILLER, 1968). The bird's feeding behavior is mostly frugivorous, but it also preys insects with some seasonal variations in its diet throughout the year (NOVOA et al., 1996). In Chile, $Z$. capensis is distributed from Arica (18²8'30"S, 70¹8'52”W) to Tierra del Fuego (5336'00”S, 69²3'00”W). Five subspecies of $Z$. capensis are endemic in Chile: $Z$. c. chilensis from Arica to Aysén; $Z$. c. antofagastae from Arica to Antofagasta; Z. c. australis in the Andes from Santiago to Aysén; Z. c. peruviensis in Arica; and Z. c. sanborni from Atacama to Valparaíso (CHESTER, 2008).

Currently, $Z$. capensis does not face any conservation issues due to its ability to exploit different environments. However, at present, there is limited information regarding the parasite fauna of South-American birds, and $Z$. capensis is no exception (HINOJOSA-SÁEZ \& GONZÁLEZ-ACUÑA, 2005). Previous studies of ectoparasites associated with $Z$. capensis recorded a number of arthropods and helminths from this bird in South America: the louse fly Ornithoctona fusciventris Wiedemann, 1830 (Diptera: Hippoboscidae) in Brazil (GRACIOLLI \& CARVALHO, 2003); mites Acarus batatas Linnaeus 1758 (Acari: Astigmata) in Guatemala (BRENNAN \& DALMAT, 1960), Amerodectes zonotrichiae Mironov and González-Acuña, 2014 (Analgoidea: Proctophyllodidae) in Chile (MIRONOV \& GONZÁLEZ-ACUÑA, 2014), Analges sp. (Analgoidea: Analgidae) and Pterodectes sp. (Analgoidea: Proctophyllodidae) (KANEGAE et al., 2008) in Brazil, Ornithonyssus bursa (Berlese, 1888) (Mesostigmata: Macronyssidae) in Argentina (SANTILLÁN et al., 2015), Mesalgoides sp. (Analgoidea: Psoroptoididae) in Brazil and Colombia (KANEGAE et al., 2008; BARRETO et al., 2012), and Trouessartia capensis Berla, 1959 (Analgoidea: Trouessartiidae) in Colombia, Argentina, Paraguay, and Brazil (SANTANA, 1976; KANEGAE et al., 2008; BARRETO et al., 2012); the lice Menopon laticorpus Carriker, 1903 (Phthiraptera: Menoponidae) in Costa Rica and Venezuela (PRICE et al., 2002) and Menacanthus bonariensis Burmeister, 1838 (Phthiraptera: Menoponidae) in Argentina (CICCHINO, 2003); and ticks Ixodes auritulus Neumann, 1904 (Acari: Ixodidea) in Chile (GONZÁLEZ-ACUÑA et al., 2005), Amblyomma aureolatum Pallas, 1772 (Acari: Ixodidae) in Brazil (GUGLIELMONE et al., 2003a), and $A$. triste Koch, 1844 in Argentina (NAVA et al., 2011). Endoparasites have rarely been reported in $Z$. capensis with records of Anonchotaenia zonotrichicola Dollfus, 1959 (Cestoda: Paruterinidae) in Peru (DOLLFUS, 1959); A. globata von Linstow, 1879 in an unspecified location of South America (RAUSCH \& MORGAN, 1947); and Lubens lubens Braun, 1901 (Digenea: Dicrocoeliidae) in Brazil (TRAVASSOS et al., 1969).

The main purpose of this study is to document new records of the ecto- and endoparasites of the rufous-collared sparrow, $Z$. capensis, in Chile.

\section{Materials and Methods}

This study was performed in seven locations throughout northern and central Chile: Llanos del Challe National Park (28 $\left.10^{\prime} \mathrm{S}, 71^{\circ} 00^{\prime} \mathrm{W}\right)$; Las Chinchillas National Reserve (31 $28^{\circ} \mathrm{S}$, $\left.71^{\circ} 03^{\prime} \mathrm{W}\right)$; Bosques de Fray Jorge National Park (30³9'S, $\left.71^{\circ} 41^{\prime} \mathrm{W}\right)$; Lago Peñuelas National Reserve (3310'S, $\left.71^{\circ} 29^{\prime} \mathrm{W}\right)$; La Campana National Park (32 $\left.{ }^{\circ} 58^{\prime} \mathrm{S}, 71^{\circ} 05^{\prime} \mathrm{W}\right)$; Tiltil (330.5' $\left.70^{\circ} 55^{\prime} \mathrm{W}\right)$; and Termas del Flaco (34 $\left.{ }^{\circ} 57^{\prime} \mathrm{S}, 7^{\circ} 25^{\prime} \mathrm{W}\right)$ (Figure 1).

Between April 2010 and August 2014, a total of 277 Z. capensis were caught using three mist nets in each locality (two $12 \times 2.8 \mathrm{~m}$ nets and one $18 \times 2.8 \mathrm{~m} \mathrm{net}$ ). The hosts were externally inspected with the naked eye and a magnifier in searching for ectoparasites. Feathers on the wings, tail, head, neck, flanks, back and abdomen were closely examined for ectoparasites. The birds were banded and released in the same place where they were captured. All capture and handling procedures were authorized by the Agricultural and Livestock Services (SAG; Resolution No2012).

Following collection, the ectoparasites were preserved in $70 \%$ ethanol. Lice were cleared using $20 \% \mathrm{KOH}$ and ascending concentrations of ethanol solutions (40\%, 70\%, and 96\%); they were subsequently mounted using Canada balsam, as indicated in Palma (1978) and Price et al. (2003). Lice were identified using the keys and descriptions of Price et al. (2003); moreover, the body measurements of these lice were taken. Mites were cleared using Nesbitt's solution ( $40 \mathrm{~g}$ of chloral hydrate, $25 \mathrm{~mL}$ of distilled water, and $2.5 \mathrm{~mL}$ of hydrochloric acid) for $72 \mathrm{~h}$, and then they were mounted in Berlese solution (KRANTZ, 1978). Mite identification was performed using keys constructed by Flechtman (1975) and Gaud \& Atyeo (1996).

In addition to the birds examined in the field, seven carcasses of the rufous-collared sparrows from the Biobío region were necropsied for endoparasites using the protocols detailed in Kinsella \& Forrester (1972). Acanthocephalans were cleared and studied in temporary mounts of $80 \%$ phenol and then returned to the preservative. These sparrows died for different reasons (i.e., they were either road killed, or they died as a result of predator attacks, poisoning, or illegal hunting), and they were subsequently brought to the Facultad de Ciencias Veterinarias of Universidad de Concepción, Chillán. Endoparasites were identified following the keys of Schmidt \& Kuntz (1977) and Amin \& Dailey (1998). Specimens collected were stored in the parasite collection from the Department of Animal Sciences, Universidad de Concepción, with access numbers CDCA-UDEC 132, CDCA-UDEC 133, CDCA-UDEC 134, CDCA-UDEC 135, CDCA-UDEC 136, and CDCA-UDEC 137.

The terminology used to describe parasitic assemblages (prevalence, mean intensity, and mean abundance) follows that of Bush et al. (1997). 'Range' displays the minimum and maximum number of individuals of a particular parasite species collected from the least and most infested hosts. The prevalence, mean intensity, mean abundance, and range were calculated for lice. In the case of mites, prevalence was the only estimated parameter, as it is extremely difficult to calculate accurately the abundance, range, and intensity of mites on live birds with the methods applied in this study. Population parameters were not obtained 


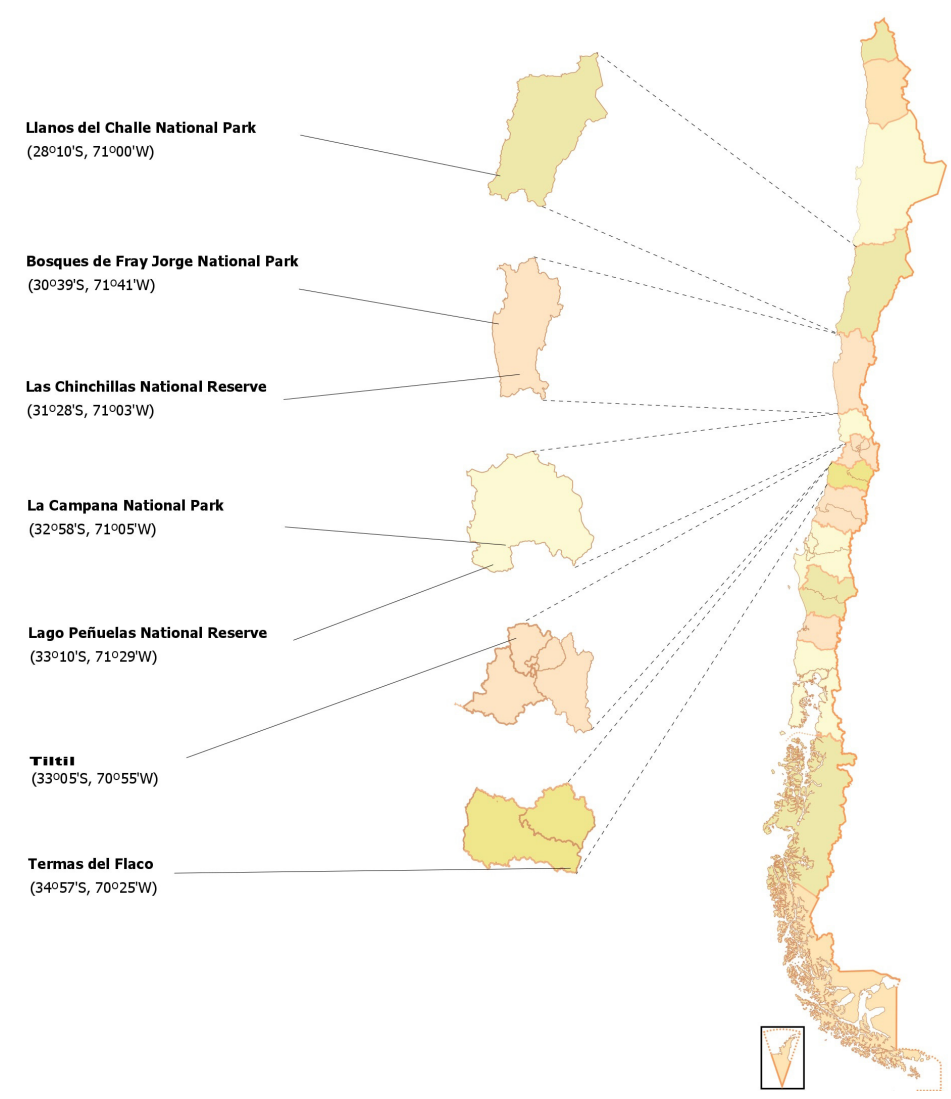

Figure 1. Locations where individuals of Zonotrichia capensis were captured during this study.

for ticks and endoparasites, because only a few individuals were collected for both groups of parasites. Ectoparasites collected from the seven rufous-collared sparrow carcasses were not considered for the numeric analysis, as in most cases, the parasites tended to abandon their former hosts after the host's death.

\section{Results and Discussion}

Ectoparasites were found in 35.8\% (99/277) of the rufous-collared sparrows examined in this study. The following groups of ectoparasites were recorded: three feather mite species from the suborder Astigmata; one chewing louse; and two ixodid tick species. In the case of endoparasites, a single specimen of Acanthocephala was recorded in two of seven necropsied sparrows.

\section{Ectoparasites}

\section{Astigmata}

Three feather mite species of the superfamily Analgoidea were found in $27.1 \%(75 / 277)$ of the sparrows examined. These mites were identified as Amerodectes zonotrichiae Mironov and GonzálezAcuña, 2014 (Figure 2), Proctophyllodes polyxenus Atyeo and Braasch, 1966 (Analgoidea: Proctophyllodidae) (Figure 3) and Trouessartia capensis Berla, 1959 (Analgoidea: Trouessartiidae) (Figure 4).

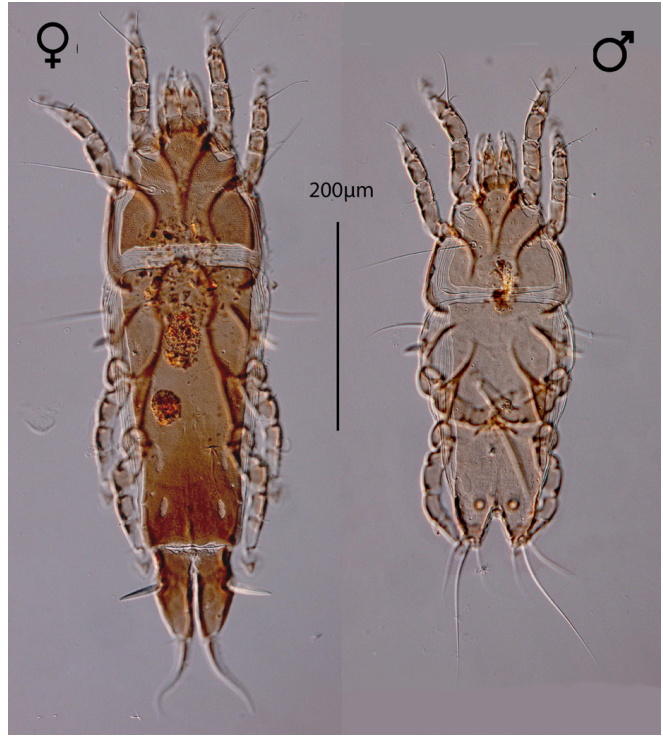

Figure 2. Female and male Amerodectes zonotrichiae (400X magnification).

Representatives of $A$. zonotrichiae were found on 1,44\% (4/277) of bird specimens. These mites were found on vanes of the wing feathers of the sparrows (mainly primaries, secondaries, tertialis and rectrices), where they were located in corridors formed by barbs. These locations are the most common for feather mites of the family Proctophyllodidae (MIRONOV \& GONZÁLEZ-ACUÑA, 


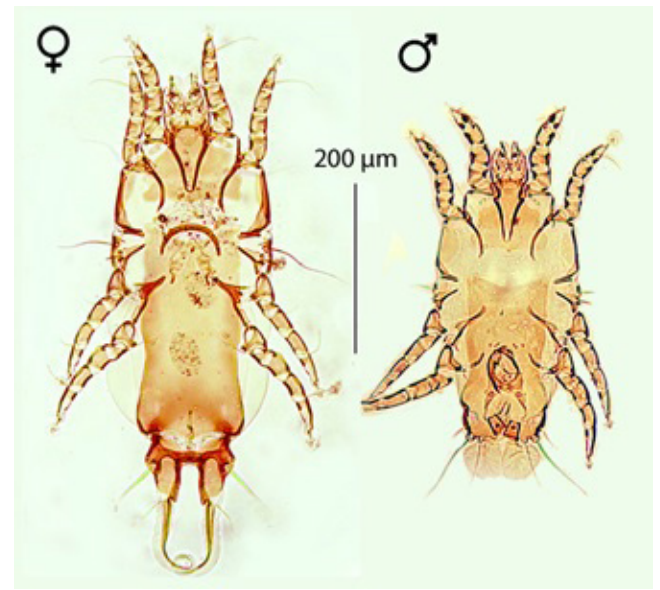

Figure 3. Female and male Proctophyllodes polyxenus (400X magnification).

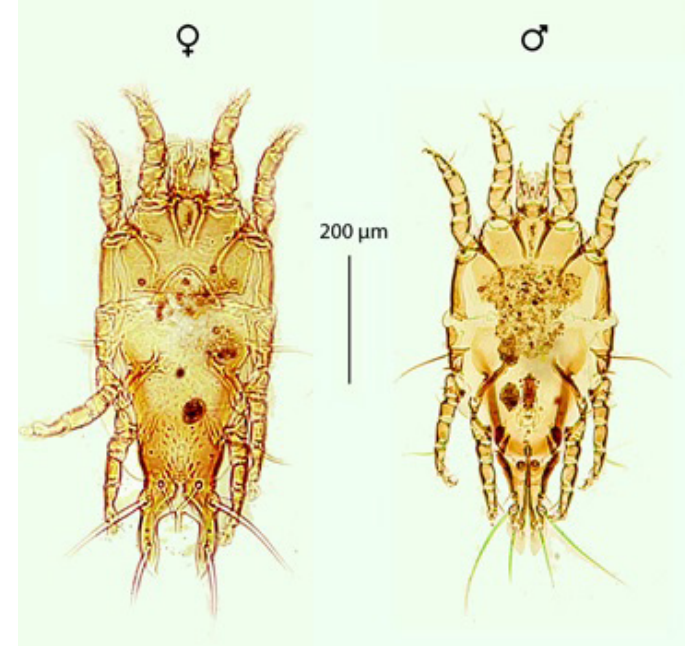

Figure 4. Female and male Trouessartia capensis (400X magnification).

2011). Specimens were collected from birds captured in Llanos del Challe National Park, Las Chinchillas National Reserve, Bosques de Fray Jorge National Park, Lago Peńuelas National Reserve, La Campana National Park and Tiltil. Of pterodectine genera restricted to passerines of the New World, the genus Amerodectes Valim and Hernandes, 2010 is the most speciose and currently includes 28 species parasitizing a wide spectrum of passerines belonging to 11 families: Cardinalidae, Emberizidae, Furnariidae, Icteridae, Mimidae, Parulidae, Thraupidae, Turdidae, Troglodytidae, Tyrannidae and Veronidae (MIRONOV et al., 2008; VALIM \& HERNANDES, 2010; MIRONOV \& GONZÁLEZ-ACUÑA, 2011, 2014; MIRONOV \& OCONNOR, 2014; MIRONOV \& OVERSTREET, 2015; HERNANDES et al., 2016). Mites of this genus has been recorded on passerines from Galapagos Islands (Ecuador) (VALIM \& HERNANDES, 2010; VILLA et al., 2013); the United States (VALIM \& HERNANDES, 2010; HRIBAR, 2013, 2014; MIRONOV \& OCONNOR, 2014; MIRONOV \& OVERSTREET, 2015); Guatemala (VALIM \& HERNANDES, 2010); Surinam (ČERNÝ, 1974; VALIM \& HERNANDES, 2010); Argentina (VALIM \& HERNANDES, 2010); Colombia (BARRETO et al., 2012); Brazil (BERLA, 1958;
VALIM \& HERNANDES, 2006, 2010; BARRETO et al., 2012; MENDES et al., 2012; ENOUT et al., 2012; SILVA et al., 2015; HERNANDES et al., 2016) and Cuba (MIRONOV \& GONZÁLEZACUÑA, 2011; MIRONOV \& GONZÁLEZ-ACUÑA, 2014). In Chile, $A$. zonotrichiae was originally found on $Z$. capensis in Atacama Region (MIRONOV \& GONZÁLEZ-ACUÑA, 2014). Other Amerodectes species were recorded in this country on Sturnella loyca (Icteridae) and Phrygilus patagonicus (Emberizidae) in Los Lagos Region, and on Sicalis luteola (Emberizidae) in Biobío Region (SOTO et al., 2013; MIRONOV \& GONZÁLEZACUÑA, 2011).

Representatives of P. polyxenus were found in 1.4\% (4/277) of the examined bird individuals. As the previous feather mite, this species is a typical inhabitant of the flight feathers of the wings and tail feathers having large and firm vanes. However, these mite, as for most proctophyllodines, usually occupy vane areas which are closer to the rachis than pterodectines (MIRONOV, 2009). Specimens of this mite were collected from sparrows captured in Bosques de Fray Jorge National Park and Tiltil. Proctophyllodes polyxenus is a feather mite uncommonly widely distributed among passerine hosts; it has been recorded so far from 37 passerine species of the families Calcariidae, Cardinalidae, Emberizidae, Motacillidae, Parulidae, Passerellidae, Thraupidae, and Turdidae in the New World. All records of this mite were made from hosts captured in the USA, Mexico, and in a minor part in Canada (Newfoundland) (ATYEO \& BRAASCH, 1966). It is necessary to note that the authors of this species admitted that this so widely distributed mite could represent in fact a complex of very closely related or cryptic species. However, this question has never been specifically examined by statistic or molecular-based methods. Among numerous passerine hosts, $P$. polyxenus was previously recorded on three sparrow species of the genus Zonotrichia, $-Z$. albicollis (Gmelin), Z. leucophrys (Forster) and Z. querula (Nuttall) in the United States (ATYEO \& BRAASCH, 1966). The present study reports $Z$. capensis as a new host of $P$. polyxenus and expands its geographical range of this mite to Chile.

The genus Proctophyllodes Robin, 1868 is the species-richest in the family Proctophyllodidae and among all families of feather mites currently including about 170 species (ATYEO \& BRAASCH, 1966; MIRONOV, 2012, 2017; WANG et al., 2014). Representatives of this genus are distributed worldwide, predominately parasitize oscine passerines and have been recorded from 35 families of this grouping (as classified by THE CORNELL LAB OF ORNITHOLOGY, 2016). Additionally, three Proctophyllodes species are found on suboscine passerines of the families Furnariidae, Pittidae, and Tyrannidae, and a single species is known from each of the following non-passerine orders, Apodiformes (Trochilidae), Charadriiformes and Piciformes (ATYEO \& BRAASCH, 1966). The world revision of the genus Proctophyllodes was carried out by Atyeo \& Braasch (1966) and this monograph is still the main taxonomic work of this genus and the only key for identification of its species. The fauna of the genus Proctophyllodes on passerines of the New World currently includes about 70 species (ATYEO \& BRAASCH, 1966; OCONNOR et al., 2005; GALLOWAY et al., 2014; MIRONOV \& OCONNOR, 2014).

Trouessartia capensis was collected from 7.2\% (20/277) of the sparrows examined. This mite was found on these birds in Las 
Chinchillas National Reserve, Bosques de Fray Jorge National Park, Lago Peñuelas National Reserve, La Campana National Park, and Tiltil.

Trouessartia capensis was originally described from $Z$. capensis subtorquata in Brazil (BERLA, 1959); it was later recorded on $Z$. capensis from Brazil and Colombia (KANEGAE et al., 2008; BARRETO et al., 2012), $Z$. capensis mellea from Argentina, $Z$. capensis subtorquata from Paraguay, and $Z$. capensis insularis from Curaçao Island (SANTANA, 1976). Our study indicates, for the first time, the presence of $T$. capensis on rufous-collared sparrows in Chile. Additionally, this mite species was previously reported from various passerines of the New World: Ammodramus savannarum floridanus (Emberizidae) from the United States (FORRESTER \& SPALDING, 2003); and Hylocryptus rectirostris (Furnariidae), Leptopogon amaurocephalus (Tyrannidae), Elaenia chiriquensis, E. cristata (Tyrannidae), Trichothraupis melanops, and Eucometis penicillata (Thraupidae) from Brazil (KANEGAE et al., 2008). However, the records of T. capensis from birds other than those from the family Emberizidae are quite questionable, and they may possibly represent misidentifications.

\section{Phthiraptera}

A total of 170 individuals belonging to the genus Philopterus Nitzsch, 1818 (Phthiraptera: Ischnocera) were identified from 10.83\% (30/277) of the rufous-collared sparrows examined (Figure 5). The genders of 82 individuals were identified, including $58.54 \%$ $(n=48)$ of nymphs and $41.46 \%(n=34)$ of adults. The Philopterus sp. was collected from this bird species across all of the sites that were visited during this study. The population parameters for Philopterus sp. are indicated in Table 1.

Lice of the genus Philopterus primarily parasitize passerine birds; it is one of the most speciose genera of the ischnoceran family Philopteridae, with more than 210 species and subspecies (PRICE \& HELLENTHAL, 1998). This is the first record of lice of the genus Philopterus on $Z$. capensis. The body measurements of the collected lice are indicated in Table 2. Louse specimens collected in this study probably represent a new species, particularly since they differ in terms of certain morphological features when compared to other known species of the same genus (PRICE \& HELLENTHAL, 1998).
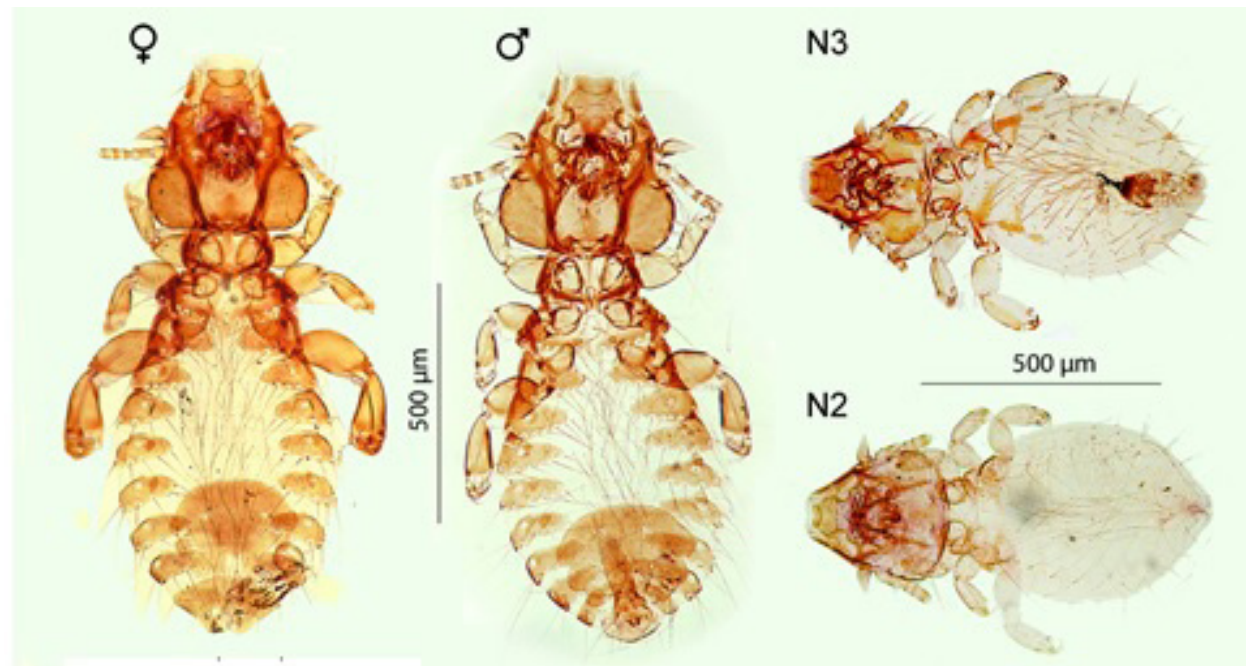

Figure 5. Female and male Philopterus sp. and two nymphs (N2 and N3) (100X magnification).

Table 1. Population parameters of Philopterus sp. collected from rufous-collared sparrows (Zonotrichia capensis).

\begin{tabular}{ccccccc}
\hline Lice & $\begin{array}{c}\text { No of captured } \\
\text { birds }\end{array}$ & Positive birds & Prevalence \% & Mean intensity & Mean abundance & Range \\
\hline Philopterus sp. & 277 & 30 & 10.83 & 5.66 & 0.61 & $1-40$ \\
\hline
\end{tabular}

Table 2. Mean body measurementss $(\mu \mathrm{m})$ of Philopterus sp. collected from rufous-collared sparrows (Zonotrichia capensis).

\begin{tabular}{|c|c|c|c|c|}
\hline \multirow{2}{*}{ Body structure } & \multicolumn{2}{|c|}{ Male } & \multicolumn{2}{|c|}{ Female } \\
\hline & Length & Width & Length & Width \\
\hline Head & 450.14 & 407.39 & 490.17 & 459.51 \\
\hline Prothorax & 116.02 & 244.98 & 129.38 & 266.07 \\
\hline Pterothorax & 128.39 & 360.54 & 161.85 & 403.95 \\
\hline Abdomen & 661.52 & 528.10 & 869.13 & 608.79 \\
\hline
\end{tabular}




\section{Ticks}

Only three tick larvae were collected from the sparrows. Two ticks were identified as Amblyomma tigrinum Koch, 1844 (Figure 6) and one as Ixodes auritulus Neumann, 1904 (Acari: Ixodidae) (Figure 7). Amblyomma tigrinum and I. auritulus were collected in the Bosques de Fray Jorge National Park and Termas del Flaco, respectively.

Amblyomma tigrinum, commonly referred to as 'the white-ribbed dog tick', parasitizes carnivores and birds in South America. Adult ticks primarily feed on domestic and wild carnivores, as well as on other members of the family Canidae; they occasionally feed on humans (GUGLIELMONE et al., 2000). During its larval and nymph stages, this tick can be found on wild birds and rodents (NAVA et al., 2006). Amblyomma tigrinum adapts to hosts living in different habitats that are found in the lowlands of Central Chile, or in high-altitude areas in the Peruvian Andes (MENDOZA \& CHÁVEZ-CHOROCCO, 2004; GONZÁLEZ-ACUNAA \& GUGLIELMONE, 2005) It has also been reported in Bolivia, Argentina, French Guiana, Paraguay, Uruguay, Venezuela, and Brazil (JONES et al., 1972; GONZÁLEZ-ACUÑA et al., 2004). In Chile, it has been described to parasitize such bird species as Nothoprocta perdicaria (Tinamidae), Callipepla californica

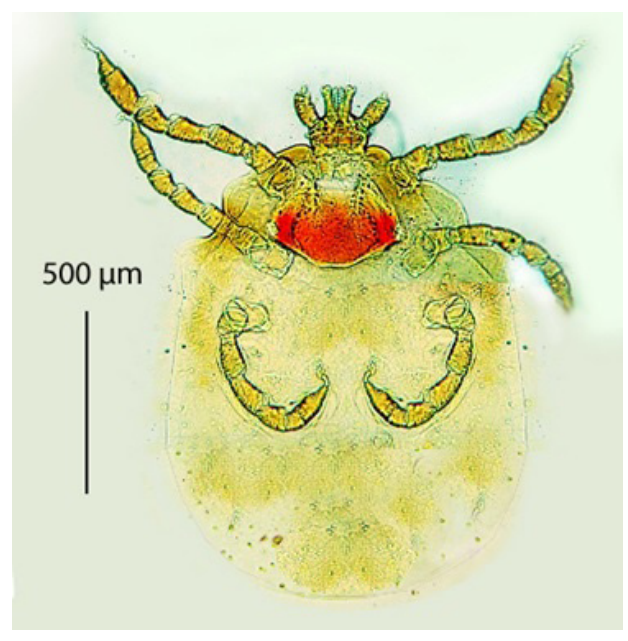

Figure 6. Amblyomma tigrinum larva (100X magnification).

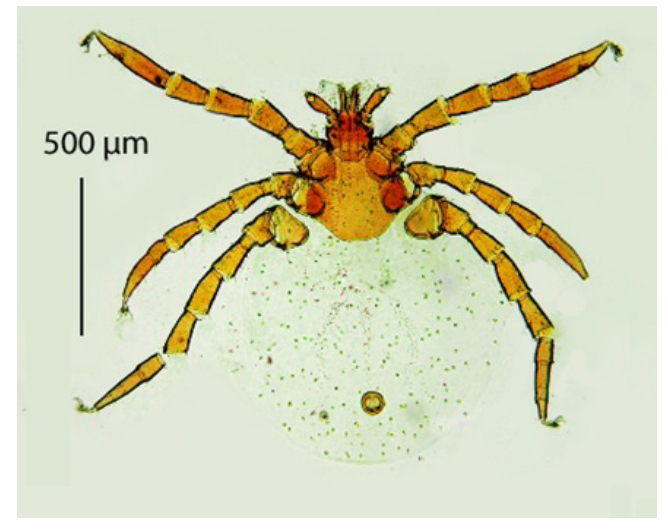

Figure 7. Ixodes auritulus larva (100X magnification).
(Odontophoridae), and Zenaida auriculata (Columbidae) (GONZÁLEZ-ACUNAA et al., 2004). It is likely that populations of $Z$. capensis and other possible host species, such as Lycalopex culpaeus, are assisting in the maintenance of the endemic status of $A$. tigrinum in Bosques de Fray Jorge National Park. This is the first record of $A$. tigrinum on $Z$. capensis.

Ixodes auritulus is commonly recorded as a parasite of land birds in South America, primarily from the Turdidae and Furnariidae families (GONZÁLEZ-ACUÑA et al., 2005). It inhabits areas with low temperatures, such as mountainous environments, or in lowlands featuring cold or temperate climates (BERMÚDEZ et al., 2015). This species has been reported from different hosts in Guatemala, Panamá, Venezuela, Costa Rica, Ecuador, Peru, Brazil, Uruguay, Argentina, and Chile, but it is also distributed in the Ethiopian, Nearctic, and Australian regions (GUGLIELMONE et al., 2003b; BERMÚDEZ et al., 2015). Its subspecies I. a. zealandicus was found on seabirds from the New Zealand sub-region (HEATH et al., 2011). In Chile, I. auritulus has been previously recorded on $Z$. capensis, Cinclodes fuscus (Furnariidae), C. antarcticus, Aphrastura spinicauda (Furnariidae), Elaenia albiceps (Tyrannidae), Pygarrhichas albogularis (Furnariidae), Troglodytes sp. (Troglodytidae), Curaeus curaeus (Icteridae), and Turdus falcklandii (Turdidae) (GONZÁLEZACUÑA et al., 2005).

\section{Endoparasites}

Two endoparasite specimens were isolated from two of the seven birds carcasses examined. Both were identified as Mediorhynchus papillosus Van Cleave, 1916 (Gigantorhynchida: Gigantorhynchidae).

The genus Mediorhynchus includes 35 species parasitizing the small intestine of wild birds all over the world (SCHMIDT \& KUNTZ, 1977). Detailed information about the life cycle of this genus is unknown for most species. Studies of M. centurorum indicated that this parasite infects cockroaches as intermediary hosts during its larval stage before being transmitted to birds through ingestion (JACKSON \& NICKOL, 1979).

Mediorhynchus papillosus has been previously recorded in a wide range of bird families, primarily in North America, with fewer reports in Eurasia. This acanthocephalan has been reported in Tringa erythropus (Scolopacidae) in Bulgaria (DIMITROVA \& GENOV, 1992); Calliope calliope (Muscicapidae) in Russia; Alauda gulgula wattersi (Alaudidae) and Dicrurus macrocercus (Dicruridae) in Taiwan; Alauda arvensis pescadores in the Pescadores Islands (SCHMIDT \& KUNTZ, 1977); Passer domesticus (Passeridae) in Brazil (BRASIL \& AMATO, 1992); and Charadrius vociferus (Charadriidae), Colinus virginianus (Odontophoridae), Contopus virens (Tyrannidae), Sayornis phoebe (Tyrannidae), Pooecetes gramineus (Emberizidae), Melospiza melodia (Emberizidae), Ammospiza maritima (Passerellidae), Agelaius phoeniceus (Icteridae), Oreoscoptes montanus (Mimidae), Petrochelidon pyrrhonota (Hirundidae), Tachycineta bicolor (Hirundidae), Porzana carolina (Rallidae), Tympanuchus cupido (Phasianidae), and Numenius americanus (Scolopacidae) in the United States (VAN CLEAVE, 1947; WEBSTER, 1948; HUNTER \& QUAY, 1953; ECKMAN, 1968; KAYTON \& SCHMIDT, 1975; BUTLER \& PFAFFENBERGER, 1981; 
SHERWIN \& SCHMIDT, 1988; WALLACE \& OLSEN, 1996; AMIN \& DAILEY, 1998; BRUNO et al., 2015).

This is the first record of $M$. papillosus from $Z$. capensis and the first record of this acanthocephalan in Chile. It is possible that $M$. papillosus infects a much wider range of bird species in Chile and South America due to its generalist behavior and cosmopolitan distribution. Additional information about its intermediary and definitive hosts is required to better understand the ecology of this parasite in South America.

This scientific work contributes to the knowledge about the prevalence and diversity of parasites occurring in $Z$. capensis, as three feather mites, $A$. zonotrichiae, P. polyxenus and T. capensis; a louse, Philopterus sp.; two ixodid ticks, A. tigrinum and A. auritulus; and an acanthocephalan, $M$. papillosus, were recorded. For the first time, this study reports the occurrence of Philopterus sp., A. tigrinum, and $M$. papillosus on $Z$. capensis, and it expands the distributional range of $T$. capensis to Chile.

\section{Acknowledgements}

We are deeply grateful for the support granted by the National Forest Corporation (CONAF) and the Agricultural and Livestock Service (SAG) of Chile. We also thank Karen Ardiles, Carolina Silva, Pedro Álvarez, Sebastián Muñoz, Daniela Doussang, Karolina Araya, Marescla Martínez, Danny Fuentes, Felix Varas, María Najle, Ivan Torres, Nicolás Fernández, Pablo Olmedo, Victor Esparza, and Diego Barrientos for all their support in the field. This research study was funded by FONDECYT Project 1130948.

\section{References}

Amin OM, Dailey MD. Description of Mediorhynchus papillosus (Acanthocephala: Gigantorhynchidae) from a Colorado, U.S.A., population, with a discussion of morphology and geographical variability.J Helminthol Soc Wash 1998; 65(2): 189-200.

Atyeo WT, Braasch NL. The feather mite genus Proctophyllodes (Sarcoptiformes: Proctophyllodidae). Nebraska: UNSM; 1966. vol. 5. Bulletin of the University of Nebraska State Museum. 354 p.

Barreto M, Burbano ME, Proctor HC, Mironov SV, Wauthy G. Feather mites (Acariformes: Psoroptidia) from Colombia: preliminary list with new records. Zootaxa 2012; 3516: 1-68.

Berla HF. Analgesidae neotropicais I - duas novas espécies de Pterodectes Robin, 1868 (Acarina-Proctophyllodinae) coletadas em Fringillidae, Aves, Passeriformes. Bol Mus Nac Zool 1958; 186: 1-6.

Berla HF. Analgesidae neotropicais II - três novas espécies de Trouessartia Canestrini, 1889 (Acarina-Proctophyllonidae) hóspedes de Fringillidae (Aves-Passeriformes). Bol Mus Nac Zool 1959; 208: 1-8.

Bermudez SE, Torres S, Aguirre Y, Domínguez L, Vega JAB. A review of Ixodes (Acari: Ixodidae) parasitizing wild birds in Panama, with the first records of Ixodes auritulus and Ixodes bequaerti. Syst Appl Acarol 2015; 20(8): 847-853. http://dx.doi.org/10.11158/saa.20.8.1.

Brasil MC, Amato SB. Faunistic analysis of the helmints of sparrows (Passer domesticus L., 1758) captured in Campo Grande, Rio de Janeiro, RJ. Mem Inst Oswaldo Cruz 1992; 87(S1): 43-48. http://dx.doi.org/10.1590/ S0074-02761992000500009.
Brennan JM, Dalmat HC. Chiggers of Guatemala (Acarina: Trombiculidae). Ann Entomol Soc Am 1960; 53(2): 183-191. http://dx.doi.org/10.1093/ aesa/53.2.183.

Bruno A, Fedynich A, Purple K, Gerhold R, Rollins D. Survey for Trichomonas gallinae in Northern Bobwhites (Colinus virginianus) from the Rolling Plains Ecoregion, Oklahoma and Texas, USA. J Wildl Dis 2015; 51(3): 780-783. PMid:25973623. http://dx.doi.org/10.7589/2015-01-011.

Bush AO, Lafferty KD, Lotz JM, Shostak AW. Parasitology meets ecology on its own terms: Margolis et al. revisited. J Parasitol 1997; 83(4): 575 583. PMid:9267395. http://dx.doi.org/10.2307/3284227.

Butler WF, Pfaffenberger GS. Notes on parasites of the long-billed curlew, Numenius americanus, from eastern New Mexico. JWildl Dis 1981; 17(4): 537-538. PMid:7338977. http://dx.doi.org/10.7589/0090-3558-17.4.537.

Černý V. Parasitic mites of Surinam. XXXI. New species of Proctophyllodidae (Sarcoptiformes, Analgoidea). Folia Parasitol 1974; 21(4): 349-361. PMid:4448437.

Chester S. A wildlife guide to Chile: Continental Chile, Chilean Antarctica, Easter Island, Juan Fernandez Archipelago. New Jersey: Princeton University Press; 2008.

Cicchino AC. Menacanthus bonariensis new species (Phthiraptera: Menoponidae), parasitic on the White-bellied Sparrow, Zonotrichia capensis hypoleuca (Todd, 1915) (Aves: Passeriformes: Fringillidae) in Buenos Aires Province, Argentina. Zootaxa 2003; 358(1): 1-11. http:// dx.doi.org/10.11646/zootaxa.358.1.1.

Dimitrova Z, Genov T. Acanthocephalans from some aquatic birds from the Bulgarian Black Sea coast. Folia Parasitol 1992; 39(3): 235-235.

Dollfus RPF. Cestodes et acanthocéphale d'oiseaux récoltés au Pérou par le Dr. Jean Dorst. Bull Soc Zool Fr 1959; 84(5-6): 384-395.

Eckman MK. Helminth parasites of the killdeer in Colorado. J Parasitol 1968; 54(6): 1143. http://dx.doi.org/10.2307/3276980.

Enout AMJ, Lobato DNC, Diniz FC, Antonini Y. Chewing lice (Insecta, Phthiraptera) and feather mites (Acari, Astigmata) associated with birds of the Cerrado in Central Brazil. Parasitol Res 2012; 111(4): 1731-1742. PMid:22773045. http://dx.doi.org/10.1007/s00436-012-3016-5.

Flechtman CHW. Elementos de Acarologia. São Paulo: Livraria Nobel S.A.; 1975.

Forrester DJ, Spalding MG. Parasites and diseases of wild birds in Florida. Gainesville: University Press of Florida; 2003.

Galloway TD, Proctor HC, Mironov SV. Chewing Lice (Insecta: Phthiraptera: Amblycera, Ischnocera) and Feather Mites (Acari: Astigmatina: Analgoidea, Pterolichoidea): Ectosymbionts of Grassland Birds in Canada. In: Cárcamo HA, Giberson DJ, editors. Arthropods of Canadian Grasslands: biodiversity and systematics - Part 1. Ottawa: Biological Survey of Canada; vol. 3. 2014. p. 139-188.

Gaud J, Atyeo WT. Feather mites of the World (Acarina, Astigmata): the supraspecific taxa. Belgium: Musée Royal de l'Afrique Centrale; 1996. 2 vol. Part I, Text -- Part II, Illustrations of feather mite taxa. (Annales [Musee Royal de l'Afrique Centrale]. Sciences Zoologiques; no. 117).

González-Acuña D, Guglielmone AA. Ticks (Acari: Ixodoidea: Argasidae, Ixodidae) of Chile. Exp ApplAcarol 2005; 35(1-2): 147-163. PMid:15777007. http://dx.doi.org/10.1007/s10493-004-1988-2.

Gonzalez-Acuña D, Venzal J, Skewes-Ramm O, Rubilar-Contreras L, Daugschies A, Guglielmone AA. First record of immature stages of Amblyomma tigrinum (Acari: Ixodidae) on wild birds in Chile. Exp 
Appl Acarol 2004; 33(1-2): 153-156. PMid:15285147. http://dx.doi. org/10.1023/B:APPA.0000030015.18088.e6.

González-Acuña D, Venzal JM, Keirans JE, Robbins RG, Ippi S, Guglielmone AA. New host and locality records for the Ixodes auritulus (Acari: Ixodidae) species group, with a review of host relationships and distribution in the Neotropical Zoogeographic Region. Exp Appl Acarol 2005; 37(1-2): 147-156. PMid:16180081. http://dx.doi.org/10.1007/ s10493-005-8434-y.

Graciolli G, Carvalho CJB. Hippoboscidae (Diptera, Hippoboscoidea) no Estado do Paraná, Brasil: chaves de identificação, hospedeiros e distribuição geográfica. Rev Bras Zool 2003; 20(4): 667-674. http:// dx.doi.org/10.1590/S0101-81752003000400019.

Guglielmone AA, Estrada-Peña A, Mangold AJ, Barros-Battesti DM, Labruna MB, Martins JR, et al. Amblyomma aureolatum (Pallas, 1772) and Amblyomma ovale Koch, 1844 (Acari: Ixodidae): hosts, distribution and 16S rDNA sequences. Vet Parasitol 2003a; 113(3-4): 273-288. PMid:12719142. http://dx.doi.org/10.1016/S0304-4017(03)00083-9.

Guglielmone AA, Estrada-Pena A, Keirans JE, Robbins RG. Ticks (Acari: Ixodida) of the Neotropical Zoogeographic Region. Houten: Special Publication of the International Consortium on Ticks and Tick-Borne Diseases, 2003b.

Guglielmone AA, Mangold AJ, Luciani CE, Viñabal AE. Amblyomma tigrinum (Acari: Ixodidae) in relation to phytogeography of centralnorthern Argentina with notes on hosts and seasonal distribution. Exp Appl Acarol 2000; 24(12): 983-989. PMid:11354625. http://dx.doi. org/10.1023/A:1010775528628.

Heath AC, Palma RL, Cane RP, Hardwick S. Checklist of New Zealand ticks (Acari: Ixodidae, Argasidae). Zootaxa 2011; 2995: 55-63.

Hernandes FA, Pedroso LG, Oniki-Willis Y. Five new feather mites of the subfamily Pterodectinae (Acariformes: Astigmata: Proctophyllodidae) from passerines and hummingbirds (Aves) of Brazil. Zootaxa 2016; 4161(3): 301-328. PMid:27615933. http://dx.doi.org/10.11646/zootaxa.4161.3.1.

Hinojosa-Sáez A, González-Acuña D. Estado actual del conocimiento de helmintos en aves silvestres de Chile. Gayana 2005; 69(2): 241-253.

Hribar LJ. Ectoparasites collected from the ovenbird (Seiurus aurocapilla) on Vaca Key, Florida. Florida Field Nat 2013; 41(4): 123-125.

Hribar LJ. Parasitic mites collected from perching birds (Aves: Passeriformes) on Vaca Key, Florida. Florida Field Natt 2014; 42(3): 119-123.

Hunter WS, Quay TL. An ecological study of the helminth fauna of Macgillivray's seaside sparrow, Ammospiza maritima macgillivraii (Audubon). Am Midl Nat 1953; 50(2): 407-413. http://dx.doi.org/10.2307/2422099.

Jackson JA, Nickol BB. Ecology of Mediorhynchus centurorum host specificity. J Parasitol 1979; 65(1): 167-169. http://dx.doi.org/10.2307/3280223.

Jones EK, Clifford CM, Keirans JE, Kohls GM. Ticks of Venezuela (Acarina: Ixodoidea) with a key to the species of Amblyomma in the Western Hemisphere. Brigham Young Univ Sci Bull 1972; 17(4): 11-18.

Kanegae MF, Valim M, Fonseca MA, Marini MÂ, Freire NMS. Ácaros plumícolas (Acari: Astigmata) em aves do cerrado do Distrito Federal, Brasil. Biota Neotrop 2008; 8(1): 31-39. http://dx.doi.org/10.1590/ S1676-06032008000100003.

Kayton RJ, Schmidt GD. Helminth parasites of the cliff swallow, Petrochelidon pyrrhonota Veillot, 1817 in Colorado, with two new species. J Helminthol 1975; 49(2): 115-119. http://dx.doi.org/10.1017/ S0022149X00023233.
Kinsella JM, Forrester DJ. Helminths of the Florida Duck, Anas platyrhynchos fulvigula. Proc Helminthol Soc 1972; 39(2): 173-176.

Krantz GW. A manual of acarology. 2nd ed. Corvallis: Oregon State University Book Stores; 1978.

Mendes MM, Amaral HLC, Hernandes FA, Müller G. Ácaros (Astigmata) em Pitangus sulphuratus (Passeriformes: Tyrannidae) na região sul do Brasil. Biologist 2012; 10(2): 89.

Mendoza L, Chávez-Chorocco J. Ampliación geográfica de siete especies de Amblyomma (Acari: Ixodidae) y primer reporte de A. oblongoguttatum Koch, 1844 para Perú. Rev Per Ent 2004; 44: 69-72.

Miller AH, Miller VD. The behavioral ecology and breeding biology of the Andean sparrow, Zonotrichia capensis. Caldasia 1968; 10(47): 83-154.

Mironov SV, González-Acuña D. New feather mites of the subfamily Pterodectinae (Acariformes: Proctophyllodidae) from passerines (Aves: Passeriformes) from Chile and Cuba. Zootaxa 2011; 3057: 1-48.

Mironov SV, González-Acuña D. Two new species of the feather mite genus Amerodectes Valim et Hernandes, 2010 (Acariformes: Proctophyllodidae) from passerines (Aves: Passeriformes) of the New World. Acarina 2014; 22(1): 3-13.

Mironov SV, Literak I, Čapek M. New feather mites of the subfamily Pterodectinae (Acari: Astigmata: Proctophyllodidae) from passerines (Aves: Passeriformes) in Mato Grosso do Sul, Brazil. Zootaxa 2008; 1(38): 2008.

Mironov SV, Oconnor BM. New species of the feather mite family Proctophyllodidae (Acariformes: Astigmata) from two species of mockingbirds (Passeriformes: Mimidae) in Eastern North America. $J$ Med Entomol 2014; 51(3): 529-546. PMid:24897846. http://dx.doi. org/10.1603/ME13109.

Mironov SV, Overstreet RM. A new species of the feather mite genus Amerodectes Valim et Hernandes, 2010 (Acariformes: Proctophyllodidae) from Xanthocephalus xanthocephalus (Passeriformes: Icteridae) In Oregon. Acarina 2015; 23(1): 74-80.

Mironov SV. New species of the feather mite genus Proctophyllodes Robin, 1877 (Acari: Analgoidea: Proctophyllodidae) from European passerines (Aves: Passeriformes), with an updated checklist of the genus. Acarina 2012; 20(2): 130-158.

Mironov SV. Phylogeny of feather mites of the subfamily Pterodectinae (Acariformes: Proctophyllodidae) and their host associations with passerines (Passeriformes). Proc Zool Inst RAS 2009; 313(2): 97-118.

Mironov SV. Two new feather mites of the genus Proctophyllodes Robin, 1868 (Acari: Proctophyllodidae) from European passerines (Aves: Passeriformes). Syst Parasitol 2017; 94(2): 215-226. PMid:28130674. http://dx.doi.org/10.1007/s11230-016-9691-3.

Nava S, Mangold AJ, Guglielmone AA. The natural hosts of larvae and nymphs of Amblyomma tigrinum Koch, 1844 (Acari: Ixodidae). Vet Parasitol 2006; 140(1-2): 124-132. PMid:16682121. http://dx.doi. org/10.1016/j.vetpar.2006.03.009.

Nava S, Mangold AJ, Mastropaolo M, Venzal JM, Fracassi N, Guglielmone AA. Seasonal dynamics and hosts of Amblyomma triste (Acari: Ixodidae) in Argentina. Vet Parasitol 2011; 181(2-4): 301-308. PMid:21536384. http://dx.doi.org/10.1016/j.vetpar.2011.03.054.

Novoa FF, Veloso C, López-Calleja MV, Bozinovic F. Seasonal changes in diet, digestive morphology and digestive efficiency in the rufous-collared sparrow (Zonotrichia capensis) in central Chile. Condor 1996; 98(4): 873-876. http://dx.doi.org/10.2307/1369876. 
OConnor BM, Foufopoulos J, Lipton D, Lindström K. Mites associated with the small ground finch, Geospiza fuliginosa (Passeriformes: Emberizidae), from the Galápagos Islands. J Parasitol 2005; 91(6): 1304-1313. PMid:16539009. http://dx.doi.org/10.1645/GE-581R.1.

Palma R. Slide-mounting of lice: a detailed description of the Canada balsam technique. NZ Entomol 1978; 6(4): 432-436. http://dx.doi.org /10.1080/00779962.1978.9722313.

Price RD, Hellenthal RA, Dalgleish RC. A review of Machaerilaemus (Phthiraptera: Amblycera: Menoponidae) from the Passeriformes (Aves), with the description of five new species. Am Midl Nat 2002; 148(1): 61-74. http://dx.doi.org/10.1674/0003-0031(2002)148[0061:ARO MPA]2.0.CO;2.

Price RD, Hellenthal RA, Palma RL, Johnson KP, Clayton DH. The chewing lice: world checklist and biological overview. Champaign: Illinois Natural History Survey; 2003.

Price RD, Hellenthal RA. Taxonomy of Philopterus (Phthiraptera: Philopteridae) from the Corvidae (Passeriformes), with descriptions of nine new species. Ann Entomol Soc Am 1998; 91(6): 782-799. http:// dx.doi.org/10.1093/aesa/91.6.782.

Rausch R, Morgan BB. The genus Anonchotaenia (Cestoda: Dilepididae) from North American birds, with the description of a new species. Trans Am Microsc Soc 1947; 66(2): 203-211. PMid:20266405. http://dx.doi. org/10.2307/3223251.

Santana FJ. A review of the genus Trouessartia: (Analgoidea: Alloptidae). J Med Entomol 1976;13(S1): 1-125. PMid:1078040. http://dx.doi. org/10.1093/jmedent/13.Suppl1.1.

Santillán MÁ, Grande JM, Liébana MS, Martínez P, Díaz LA, Bragagnolo LA, et al. New hosts for the mite Ornithonyssus bursa in Argentina. Med Vet Entomol 2015; 29(4): 439-443. PMid:26258483. http://dx.doi. org/10.1111/mve.12129.

Schmidt GD, Kuntz RE. Revision of Mediorhynchus Van Cleave 1916 (Acanthocephala) with a key to species. J Parasitol 1977; 63(3): 500-507. PMid:559066. http://dx.doi.org/10.2307/3280011.

Sherwin FJ, Schmidt GD. Helminths of swallows of the mountains of Colorado, including Acuaria coloradensis n. sp. (Nematoda: Spirurata). J Parasitol 1988; 74(2): 336-338. PMid:3357125. http://dx.doi. org/10.2307/3282465.
Silva HM, Hernandes FA, Pichorim M. Feather mites (Acari, Astigmata) associated with birds in an Atlantic Forest fragment in northeastern Brazil. Braz J Biol2015; 75(3): 726-735. PMid:26421767. http://dx.doi. org/10.1590/1519-6984.23313.

Soto M, Moreno L, Sepúlveda MS, Kinsella JM, Mironov S, GonzálezAcuña D. First records of parasites from the Long-tailed Meadowlark Sturnella loyca (Passeriformes: Icteridae) from the Biobío Region, Chile. Rev Mex Biodivers 2013; 84(4): 1316-1320. http://dx.doi.org/10.7550/ rmb.34112.

The Cornell Lab of Ornithology. The eBird/Clements checklist of birds of the world v2016 [online]. Ithaca: Cornell University; 2016 [cited 2016 Aug 10]. Available from: http://www.birds.cornell.edu/clementschecklist/ download

Travassos L, Freitas JFT, Kohn A. Trematódeos do Brasil. Rio de Janeiro: Instituto Oswaldo Cruz; 1969. vol. 67. PMid:5397756.

Valim MP, Hernandes FA. Redescriptions of four species of the feather mite genus Pterodectes Robin, 1877 (Acari: Proctophyllodidae: Pterodectinae) described by Herbert F. Berla. Acarina 2006; 14(1): 41-55.

Valim MP, Hernandes FA. A systematic review of feather mites of the Pterodectes generic complex (Acari: Proctophyllodidae: Pterodectinae) with redescriptions of species described by Vladimír Černý. Acarina 2010; 18(1): 3-35.

Van Cleave HJ. The acanthocephalan genus Mediorhynchus, its history and a review of the species occurring in the United States. J Parasitol 1947 33(4): 297-315. PMid:20256979. http://dx.doi.org/10.2307/3273358.

Villa SM, Bohec C, Koop JA, Proctor HC, Clayton DH. Diversity of feather mites (Acari: Astigmata) on Darwin's Finches. J Parasitol 2013; 99(5): 756-762. PMid:23691947. http://dx.doi.org/10.1645/12-112.1.

Wallace JH, Olsen OW. Endoparasites of the red-winged blackbird Agelaius phoeniceus L. in Colorado. Bull Wild Dis Assoc 1996; 2(3): 80-80. http:// dx.doi.org/10.7589/0090-3558-2.3.80.

Wang Z, Wang J, Su X. Four new feather mite species of the genus Proctophyllodes Robin (Astigmata: Proctophyllodidae) from China. Zool Syst 2014; 39(2): 248-258.

Webster JD. A new acanthocephalan from the bob-white. J Parasitol 1948; 34(2): 84-86. PMid:18856285. http://dx.doi.org/10.2307/3273397. 